\title{
COMPARATIVE STUDIES OF THE CHEMICAL CHANGES OCCURRING IN SULFONAMIDE DRUGS DURING THERAPY IN MAN
}

\author{
By D. ROURKE GILLIGAN, with the technical assistance of EDITH M. BECK \\ (From The New York Hospital and the Department of Medicine, Cornell University \\ Medical College, New York City)
}

(Received for publication July 25, 1944)

\section{INTRODUCTION}

That sulfanilamide becomes acetylated to a considerable extent in man and in some animals has been amply demonstrated ( 1 to 3 ). This acetylation occurs on the amino group of the compound (1 to 3 ) to yield $\mathrm{N}^{4}$ acetylsulfanilamide, ${ }^{1}$ a compound which has little if any bacteriostatic activity (2). It has since been found that, in man, all of the sulfonamide compounds now in common clinical usage become $\mathrm{N}^{4}$ conjugated to a greater or lesser extent (2, 5 to 11$)$. This conjugation has been shown for most of these drugs $(2,5$ to 7$)$ to be acetylation; $\mathrm{N}^{4}$ conjugates with groups other than the acetyl have not been isolated.

That sulfapyridine is "detoxified" in vivo in the dog by chemical changes other than acetylation has recently been demonstrated (12 to 14$)$ by the isolation of a glycuronide of a hydroxy derivative of sulfapyridine from the urine of dogs fed this drug. Also, a large increase in the urinary glycuronide excretion has been observed in man (15) and in the rat (16) following the ingestion of sulfapyridine, and some increase in the rat (16) following the ingestion of sulfathiazole.

These latter observations prompted the present study of the comparative extents to which several different sulfonamide drugs now in common clinical usage become acetylated, glycuronidated, and sulfated in man. The importance of such pharmacological studies in man resides in the fact that the therapeutic activity and toxicity of a drug depend not only upon the properties of the drug administered, but also upon the properties and the amounts of the products formed from the drug by chemical changes in the body.

\footnotetext{
1 The nomenclature of Crossley et al. (4), according to which $\mathrm{N}^{1}$ refers to substituents on the amide nitrogen of the sulfanilamido radical and $\mathrm{N}^{*}$ to substituents of the amino nitrogen, is used throughout this report.
}

\section{MATERIAL AND METHODS OF STUDY}

\section{Material}

The subjects of this investigation were 10 adult patients on the medical services of The New York Hospital, who received sulfonamide drugs in the treatment of various infections. For the purposes of study or for other reasons, as explained below in the legends to the figures, several patients received two different sulfonamide drugs at different times during the course of therapy.

In none of the subjects was there any recognized abnormal liver function. Similarly, 8 of the subjects had no recognized abnormal kidney function. Of the 2 subjects who received sulfonamide treatment for urinary tract infections, 1 (J. E. Figure 2) had only a left kidney, the right having been removed surgically for nephrolithiasis, and the other (B. K. Figure 10) had chronic pyelonephritis with pyelographic evidences of decreased excretory function in the left kidney. Neither of these 2 subjects had nitrogen retention. All of the subjects, except the 2 treated for urinary tract infections, had elevated body temperatures at the onset of sulfonamide therapy, and the therapy was continued for 2 or more days after the patient became afebrile.

Sulfonamide therapy was given orally in divided doses. No other medications which were known or suspected to affect the glycuronide or ethereal sulfate excretions were given during the course of the studies, except for the administration of acetylsalicylic acid in subject M. C. (Figure 9) on 2 days after the cessation of sulfonamide therapy. All of the patients treated with sulfadiazine, sulfamerazine, and sulfathiazole and 1 (M. C. Figure 9) treated with sulfamethazine received concomitantly 15.6 grams daily of sodium bicarbonate in divided doses as a precaution against renal complications consequent to therapy with these drugs (7).

\section{METHODS}

The urines were collected under toluol in 24-hour amounts. An aliquot was stored in the refrigerator under toluol alone, and to another aliquot similarly stored, 1 per cent of concentrated $\mathrm{HCl}$ was added. Free and total sulfonamide measurements were made on the unacidified specimens within a week of the urine collection. In 2 instances (J. E. Figure 2 and B. K. Figure 10 ), only total sulfonamide was measured because only acidified specimens stored at room temperature were available. The acidified stored specimens were used for glycuronic acid and sulfate measurements throughout. 
Measurements of the concentrations of the sulfonamides in the blood and urine were made by the method of Bratton and Marshall (17). Throughout this report, the term "free" refers simply to the amount of compound, calculated on the basis of the molecular weight of the drug administered, which was diazotizable without hydrolysis, i.e., had a free amino group. Similarly, the term "total" refers to the total amount of compound which was diazotizable after acid hydrolysis. That portion of the drug which became diazotizable only after hydrolysis is referred to as " $\mathrm{N}^{4}$ conjugated compound" (4). That "free compound" or " $\mathrm{N}$ " conjugated compound" are not necessarily synonymous with "free drug" or " $N^{4}$ conjugated drug" is evident from the results and discussion of the present study.

Glycuronic acid measurements were made essentially according to the method of Maughan, Evelyn, and Brown (18), which involves acid hydrolysis of the glycuronides in the urine and a color reaction between the total glycuronic acid and naphthoresorcinol. Two different samples of naphthoresorcinol purchased from Schwarz Laboratories, Inc., New York, were found readily soluble and satisfactory. It has been our practice to make up a 0.2 per cent solution of the compound in water, preserve it in a dark bottle in the refrigerator over night, and filter the next day before using. The solution so stored has kept satisfactorily for about 10 days, after which time there is considerable color development in the blank. A stock standard in water equivalent to $40 \mathrm{mgm}$. of glycuronic acid per $100 \mathrm{ml}$. was prepared from pure sodium pregnandiol glycuronidate and was found to be stable in the refrigerator for at least 4 months. From this stock solution, standards equivalent to $1 \mathrm{mgm}$. and 2 mgm. of glycuronic acid per $100 \mathrm{ml}$. were made up monthly and preserved in the refrigerator. The reaction between naphthoresorcinol and glycuronic acid is slow (19). At the end of the 30-minute interval in the boiling water bath (18), only approximately 50 per cent of the complete reaction is obtained for urines or for the standards, the reaction not being complete until after approximately 3 hours in the bath. Although presumably it would be more nearly ideal to allow 3 hours of boiling, this was not found feasible due to the development of a cloudiness in the ether layer after extraction of the colored compound. Since some slight variations in the color development of the standards were found on different runs with the 30 -minute boiling, we have practised including a water blank and the 1 and $2 \mathrm{mgm}$. standards with each set of unknown urines, diluted to contain from 0.5 to $1.5 \mathrm{mgm}$. of glycuronic acid per 100 $\mathrm{ml}$., and have calculated the concentrations in the unknowns. from the standard curve for the run, using a straight line from the origin to the point for $1 \mathrm{mgm}$. per $100 \mathrm{ml}$. It has been our practice to shake the solution for a few seconds after the addition of the alcohol, and to shake for 40 seconds with the ether to insure maximum extraction of the colored compound. The glycuronic acid values reported have been corrected for the brown contaminant in urine (18) by obtaining colorimeter readings with both the $565 \mathrm{~m} \mu$ and $440 \mathrm{~m} \mu$ filter, and by applying the following equations:

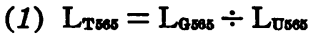

$$
\begin{aligned}
& \text { (2) } \mathrm{L}_{\mathrm{T} 440}=\mathrm{L}_{\mathrm{G440}} \div \mathrm{L}_{\mathrm{D440}}
\end{aligned}
$$

In these equations, $L_{T s o s}$ and $L_{T 40}$ are the total optical densities found with these filters, respectively, for the unknown; $L_{G s e s}$ and $L_{0 s s}$ are the optical densities contributed by the glycuronic acid and the urine contaminant, respectively, at $565 \mathrm{~m} \mu$; and $L_{0440}$ and $L_{040}$ are the optical densities contributed by these substances, respectively, at $440 \mathrm{~m} \mu$. Equation (2) may be converted to

$$
\text { (3) } L_{T 440}=G_{\text {LA10:Ises }} L_{\text {Gses }} \div U_{\text {LA40:LESS }} L_{\text {Ubes }}
$$

in which $G_{\text {LA10:Lses }}$ is the ratio of the optical densities found for pure glycuronic acid with the two filters and $U_{\text {LA10:Lsas }}$ is the ratio of the optical densities found for the brown contaminant of urine with the two filters. From measurements made with standards in water, the value of $G_{\text {Lato:Lses }}$ was found to be 0.1 . From spectrophotometric data (18), the value of $U_{\text {LA10:LSos }}$ was found to be 5.8. Substituting these values in equation (3), the following equation was obtained:

$$
\text { (4) } \mathrm{L}_{\mathrm{THO}}=0.1 \mathrm{~L}_{\mathrm{Gses}} \div 5.8 \mathrm{~L}_{\text {UBes }}
$$

On combining equations (1) and (4) and solving for Lass, the following working equation, which gives the corrected optical density for the glycuronic acid, was obtained :

$$
\text { (5) } \mathrm{L}_{\mathrm{Gbes}}=\frac{5.8 \mathrm{~L}_{\mathrm{T} 895}-\mathrm{L}_{\mathrm{T} 40}}{5.7}
$$

The corrected values were usually from 20 to $40 \mathrm{mgm}$. per day less than the values uncorrected for the $440 \mathrm{~m} \mu$ filter reading. In almost all instances, the results reported are the average of duplicates measured on two different occasions; the results of the two analyses usually agreed well within \pm 5 per cent of their average.

Measurements of urinary inorganic and ethereal sulfate were made by the benzidene titration method of Fiske (20). Approximately half of the measurements were run in duplicate; the duplicates almost always agreed within the extent of a variation of \pm 1 per cent from the average calculated percentage of ethereal sulfate.

\section{RESULTS}

The dosages of the different sulfonamide drugs studied, the diseases for which they were given, and the urinary excretions of free and total sulfonamide compound, of ethereal sulfates (in percentage of total sulfate), and of glycuromides (expressed as glycuronic acid) are reported for each subject in graphic form (Figures 1 to 10 inclusive). These data, together with the average free and total blood levels of sulfonamide during ther- 
TABLE I

Summary of the data of this study

\begin{tabular}{|c|c|c|c|c|c|c|c|c|c|c|c|c|c|c|c|c|}
\hline \multirow{2}{*}{$\begin{array}{l}\text { Patient and } \\
\text { figure } \\
\text { number }\end{array}$} & \multirow{2}{*}{ Sex } & \multirow{2}{*}{$\begin{array}{c}\text { Drug admin- } \\
\text { istered }\end{array}$} & \multirow{2}{*}{$\begin{array}{l}\text { Daily } \\
\text { dosage } \\
\text { of drug } \\
\text { during } \\
\text { study }\end{array}$} & \multirow{2}{*}{$\begin{array}{l}\text { Num- } \\
\text { ber } \\
\text { of } \\
\text { days } \\
\text { studied } \\
\text { during } \\
\text { ther- } \\
\text { apy }\end{array}$} & \multicolumn{3}{|c|}{$\begin{array}{l}\text { Average blood } \\
\text { level of sulfonamide } \\
\text { compound }\end{array}$} & \multicolumn{3}{|c|}{$\begin{array}{l}\text { Average urinary } \\
\text { excretion of sulfona- } \\
\text { mide compound }\end{array}$} & \multicolumn{2}{|c|}{$\begin{array}{c}\text { Average } \\
\text { daily total } \\
\text { sulfate } \\
\text { excretion }\end{array}$} & \multicolumn{2}{|c|}{$\begin{array}{l}\text { Average } \\
\text { ethereal } \\
\text { sulfate } \\
\text { excretion }\end{array}$} & \multicolumn{2}{|c|}{$\begin{array}{l}\text { Average } \\
\text { daily } \\
\text { glycuronate } \\
\text { excretion }\end{array}$} \\
\hline & & & & & Free & Total & $\begin{array}{c}\text { N4 } \\
\text { conju- } \\
\text { gated }\end{array}$ & Free & Total & $\begin{array}{l}\text { N4 } \\
\text { conju- } \\
\text { gated }\end{array}$ & $\begin{array}{l}\text { Dur- } \\
\text { ing } \\
\text { con- } \\
\text { trol }\end{array}$ & $\begin{array}{l}\text { Dur- } \\
\text { ing } \\
\text { ther- } \\
\text { apy }\end{array}$ & $\begin{array}{l}\text { Dur- } \\
\text { ing } \\
\text { con- } \\
\text { trol }\end{array}$ & $\begin{array}{l}\text { Dur- } \\
\text { ing } \\
\text { ther- } \\
\text { apy }\end{array}$ & $\begin{array}{c}\text { Dur- } \\
\text { ing } \\
\text { con- } \\
\text { trol }\end{array}$ & $\begin{array}{l}\text { Dur- } \\
\text { ing } \\
\text { ther- } \\
\text { apy }\end{array}$ \\
\hline & & & grams & & \multicolumn{2}{|c|}{$\begin{array}{l}\text { mgm. per } \\
100 \mathrm{ml} .\end{array}$} & $\begin{array}{l}\text { per } \\
\text { cent }\end{array}$ & \multicolumn{2}{|c|}{ grams } & $\begin{array}{l}\text { per } \\
\text { cent }\end{array}$ & \multicolumn{2}{|c|}{$\begin{array}{l}\text { grams } \\
\text { sulfur }\end{array}$} & \multicolumn{2}{|c|}{$\begin{array}{l}\text { per cent of } \\
\text { total sulfate }\end{array}$} & \multicolumn{2}{|c|}{$\underset{\text { ronic acid }}{\operatorname{mggm}}$ glycu- } \\
\hline H. W. Fig. 1 & \& & Sulfanilamide & $\begin{array}{l}7 \text { to } 3 \\
\text { (av. 5.5) }\end{array}$ & 4 & 12.3 & 15.2 & 19 & 2.49 & 3.94 & 38 & 0.67 & 0.53 & 4 & 9 & 395 & 340 \\
\hline J. E. Fig. 2 & क & Sulfadiazine & 4 & 28 & 7.2 & & & & 2.85 & & & & & & 505 & 535 \\
\hline L. L. Fig. 3 & $0^{\circ}$ & Sulfadiazine & 6 & 6 & 6.5 & & & 3.63 & 4.98 & 27 & & & & & $525 *$ & 480 \\
\hline A. H. Fig. 4 & 8 & Sulfapyrazine & 12 & 6 & 3.8 & 4.3 & 12 & 2.96 & 3.91 & 24 & 0.77 & 0.60 & 7 & 9 & 625 & 625 \\
\hline O. P. Fig. 5 & $\sigma^{\circ}$ & Sulfathiazole & 6 & 3 & 6.0 & 6.5 & 8 & 4.47 & 5.28 & 15 & 0.69 & 0.57 & 4 & 7 & 470 & 630 \\
\hline B. D. Fig. 6 & \% & $\begin{array}{l}\text { Sulfadiazine } \\
\text { Sulfamerazine }\end{array}$ & $\begin{array}{l}6 \\
6\end{array}$ & 2 & $\begin{array}{r}8.5 \\
16.7\end{array}$ & 17.3 & 3 & $\begin{array}{l}4.20 \\
3.81\end{array}$ & $\begin{array}{l}5.02 \\
5.52\end{array}$ & $\begin{array}{l}16 \\
31\end{array}$ & $\begin{array}{l}0.43 \\
0.43\end{array}$ & $\begin{array}{l}0.30 \\
0.34\end{array}$ & $\begin{array}{l}5 \\
5\end{array}$ & 12 & $\begin{array}{l}445 \\
445\end{array}$ & $\begin{array}{l}465 \\
895\end{array}$ \\
\hline M. R. Fig. 7 & q & Sulfamerazine & $\begin{array}{l}\mathbf{6} \\
\mathbf{3}\end{array}$ & 2 & $\begin{array}{l}16.5 \\
10.2\end{array}$ & $\begin{array}{l}17.6 \\
11.1\end{array}$ & $\begin{array}{l}6 \\
8\end{array}$ & $\begin{array}{l}3.20 \\
1.66\end{array}$ & $\begin{array}{l}4.88 \\
2.67\end{array}$ & $\begin{array}{l}34 \\
37\end{array}$ & $\begin{array}{l}0.60 \\
0.60\end{array}$ & $\begin{array}{l}0.64 \\
0.59\end{array}$ & $\begin{array}{l}6 \\
6\end{array}$ & $\begin{array}{l}6 \\
5 *\end{array}$ & $\begin{array}{l}480 \\
480\end{array}$ & $\begin{array}{r}1290 \\
925\end{array}$ \\
\hline R. N. Fig. 8 & $0^{7}$ & $\begin{array}{l}\text { Sulfapyridine } \\
\text { Sulfadiazine }\end{array}$ & $\begin{array}{c}4 \text { to } 6 \\
\text { (av. } 5.3 \text { ) } \\
8 \text { to } 6 \\
\text { (av. 6.2) }\end{array}$ & $\begin{array}{l}4 \\
8\end{array}$ & $\begin{array}{r}13.0 \\
8.2\end{array}$ & 14.9 & 13 & $\begin{array}{l}2.30 \\
3.82\end{array}$ & $\begin{array}{l}3.79 \\
4.45\end{array}$ & $\begin{array}{l}39 \\
14\end{array}$ & 0.54 & 0.95 & 9 & 9 & $\begin{array}{l}535 \\
535\end{array}$ & $\begin{array}{r}1670 \\
510\end{array}$ \\
\hline M. C. Fig. 9 & \& & $\begin{array}{l}\text { Sulfamethazine } \\
\text { Sulfadiazine }\end{array}$ & $\begin{array}{l}6 \\
6\end{array}$ & $\begin{array}{l}3 \frac{1}{2} \\
4\end{array}$ & $\begin{array}{l}5.1 \\
8.1\end{array}$ & $\begin{array}{l}9.4 \\
8.9\end{array}$ & $\begin{array}{r}46 \\
9\end{array}$ & $\begin{array}{l}1.34 \\
4.02\end{array}$ & $\begin{array}{l}6.00 \\
5.12\end{array}$ & $\begin{array}{l}78 \\
21\end{array}$ & $\begin{array}{l}0.87 \\
0.87\end{array}$ & $\begin{array}{l}0.38 \\
0.74\end{array}$ & $\begin{array}{l}5 \\
5\end{array}$ & $\begin{array}{l}6 \\
8\end{array}$ & $\begin{array}{l}605 \\
605\end{array}$ & $\begin{array}{r}1210 \\
760\end{array}$ \\
\hline B. K. Fig. 10 & $\sigma^{x}$ & Sulfamethazine & 4 & 6 & 6.9 & 8.6 & 20 & & 2.93 & & & & & & 500 & 1800 \\
\hline
\end{tabular}

* Only 1 day of study.

apy and in the total sulfate excretion, are summarized in Table I.

Blood and urinary free and total sulfonamides. The daily amount of total sulfonamide excreted in the urine by these patients ranged between 71 and 100 per cent of the daily dosage for all of the drugs studied except sulfapyrazine, where the urinary output of total compound was only 33 per cent of the intake (Figure 10).

The percentage of $\mathrm{N}^{4}$ conjugated compound excreted was less than 30 per cent for sulfadiazine, sulfathiazole, and sulfapyrazine, from 30 to 40 per cent for sulfanilamide and sulfamerazine, and 78 per cent in a patient receiving sulfamethazine (Figure 9). The difference in the tendency of a given drug to become $\mathrm{N}^{4}$ conjugated is shown particularly well in the studies where two drugs were administered at different times to the same individual. Thus in $R$. N. (Figure 8), 39 per cent of the excreted compound was $\mathrm{N}^{4}$ conjugated during therapy with sulfapyridine compared with only 14 per cent during sulfadiazine therapy. Similarly in B. D. (Figure 6), 31 per cent of the excreted compound was $\mathrm{N}^{4}$ conjugated during therapy with sulfamerazine and only 16 per cent with sulfadiazine. Most striking was the finding in M. C. (Figure 9) that 78 per cent of the excreted compound was $\mathrm{N}^{4}$ conjugated during sulfamethazine therapy, as against only 21 per cent during subsequent sulfadiazine therapy. This tendency for sulfamethazine to become $\mathrm{N}^{4}$ conjugated to a great extent is also obvious in the findings that, in the two patients treated with this drug, averages of 20 and 46 per cent of the blood sulfonamide compound were not diazotizable until after acid hydrolysis (Table I).

Urinary ethereal sulfate excretion. Both during sulfonamide therapy and control periods, the daily amount of total sulfate excreted in the urine was variable in different individuals, and in the same individual on different days, as was to be expected since the dietary intakes were not controlled. The differences in the average daily urinary excretions of total sulfate in a given individual were not so great between periods of therapy and control (Table I) as to affect appreciably the percentage of sulfate to be expected in the form of ethereal sulfate (21). Neither the 
amount of ethereal sulfate nor the percentage of total sulfate excreted as ethereal sulfate in the urine was consistently increased above normal during therapy with any of the drugs of this study. In two instances, H. W. (Figure 1) and B. D. (Figure 6), the values for the percentages of total sulfate excreted as ethereal sulfate during periods of therapy with sulfanilamide and sulfamerazine, respectively, were approximately twice the values obtained during the respective control periods. The authors do not believe that these differences necessarily indicate that a portion of these sulfonamides became sulfated. It is to be noted that in another subject, M. R. (Figure 7), who received sulfamerazine, no increased ethereal sulfate excretion was observed during this therapy (Table I). If the increase in ethereal sulfate were interpreted as indicating that a sulfated sulfonamide compound had been formed, calculations from the data for the increased amount of ethereal sulfate excreted (Table I) and from the molecular weights of the drugs administered and the atomic weight of sulfur show that only 0.11 gram of the daily excretion of 3.94 grams of total sulfanilamide in H. W. (Figure 1), and only 0.16 gram of the daily excretion of 5.52 grams

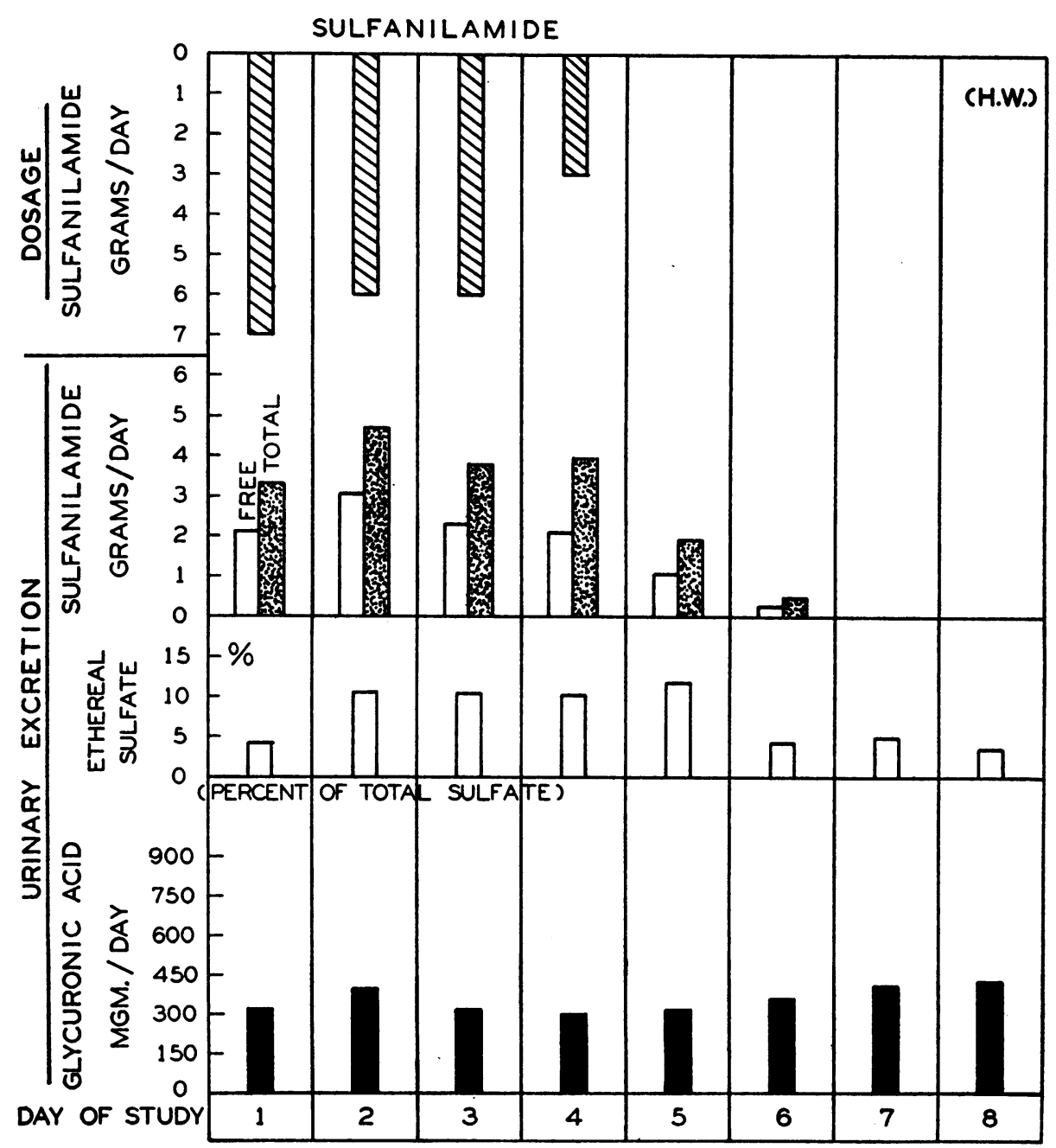

Fig. 1. Sulfanilamide

Patient H. W., a girl aged 13, received 7 to 3 grams (av. 5.5 grams) of sulfanilamide daily for 4 days in the treatment of a beta hemolytic streptococcus infection of the throat. The excretion studies started with the initiation of sulfanilamide therapy. 


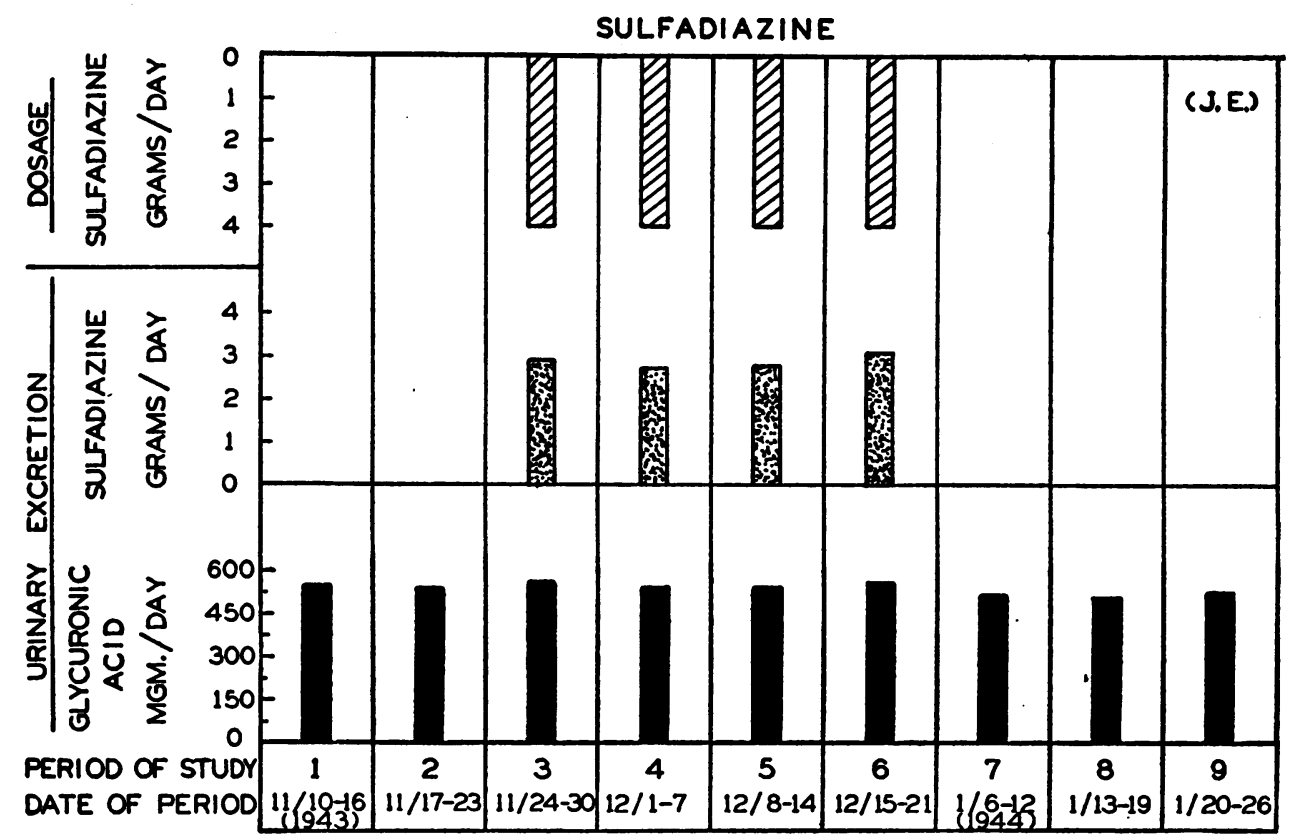

Fig. 2. Sulfadiazine

Patient J. E., an adult male, received 4 grams of sulfadiazine daily for 28 days in the treatment of a urinary tract infection with non-hemolytic streptococcus, gamma, and $B$. lactis aerogenes. The urines from this patient were combined for study * in 7-day periods. Studies were made on 2 control periods just prior to sulfadiazine therapy, on 4 periods of sulfadiazine therapy, and on 3 control periods which began approximately 2 weeks after the cessation of therapy.

* We are indebted to Dr. Ephraim Shorr for affording us the opportunity to study these specimens collected by him on the Research Metabolism ward of The New York Hospital, in affiliation with the Russell Sage Institute of Pathology, for the purpose of other studies. The urines in this instance had been preserved for several months with sulfuric acid so that the percentage of $\mathrm{N}^{4}$ conjugated sulfonamide was not measurable because of interim hydrolysis. Sulfate excretion studies also were not possible because of the addition of the sulfuric acid.

of total sulfamerazine in B. D. (Figure 6) were excreted in this form.

Urinary glycuronide excretion. The urinary glycuronide excretion (measured as glycuronic acid) was normal during sulfanilamide therapy in the 1 patient studied (Figure 1), during sulfadiazine therapy in 4 patients (Figures $2,3,6,8$ ), and during sulfapyrazine therapy in 1 patient (Figure 4) (Table I). In the 1 study with sulfathiazole, the glycuronide excretion, although not above the upper limit of normal excretion which may be encountered, was definitely and consistently higher during therapy than after its cessation (Figure 5, and Table I). The glycuronide excretions were strikingly increased above normal in 1 patient during therapy with sulfapyridine (Figure 8), in 2 patients while receiving sulfa- merazine (Figures 6, 7), and in 2 patients while receiving sulfamethazine (Figures 9,10 ); in each of these patients the glycuronide excretion returned to normal values on cessation of sulfonamide therapy. Again, the differences in glycuronide excretion encountered with different sulfonamide drugs are particularly well demonstrated in instances where two drugs were given at different times during therapy in the same patient. Thus, in R. N. (Figure 8), the glycuronide excretion fell from the very high levels obtained during sulfapyridine therapy to normal during subsequent sulfadiazine therapy. In B. D. (Figure 6), the glycuronide excretion was normal during sulfadiazine therapy but increased strikingly when therapy with this drug was replaced by sulfamerazine. In M. C. (Figure 9), the glycuronide 
excretion was strikingly increased during sulfamethazine therapy but decreased toward normal when the therapy was changed to sulfadiazine.

It is of note that the percentage of sulfonamide compound excreted as a glycuronide increased gradually during the first 3 days of sulfamethazine therapy in M. C. (Figure 9) and of sulfapyridine therapy in R. N. (Figure 8). Similarly, the percentage of compound excreted in the $\mathrm{N}^{4}$ conjugated form gradually increased in these subjects.

From calculations based on the assumption that the glycuronides excreted during therapy with sulfathiazole, sulfapyridine, sulfamerazine, and sulfamethazine were monoglycuronides, it appears that the percentage of the total sulfonamide excreted as a glycuronidated compound varied from 4 per cent in a patient receiving sulfathiazole to 68 per cent in a patient receiving sulfamethazine (Table II).

\section{DISCUSSION}

The studies of the present investigation were made directly in man since it is well known that the processes of "detoxication" of foreign substances may vary greatly in different species (22). That this is true in respect to the sulfonamides is demonstrated by the fact that certain of these compounds which become $\mathrm{N}^{4}$ acetylated in man $(2,5,6)$ also-become $\mathrm{N}^{4}$ acetylated in the rabbit and mouse (2) but do not undergo this chemical change in the dog $(1,14)$. On the other hand, in the $\operatorname{dog}$ (12 to 14$)$, and in the rat (16), as well as in man (15) (Figure 8), the urinary excretion of glycuronide is greatly increased by sulfapyridine administration. In the rat (16) as well as in man (Figure 5), there is some increased glycuronide excretion with sulfathiazole, but no increase in either the rat (16) or man

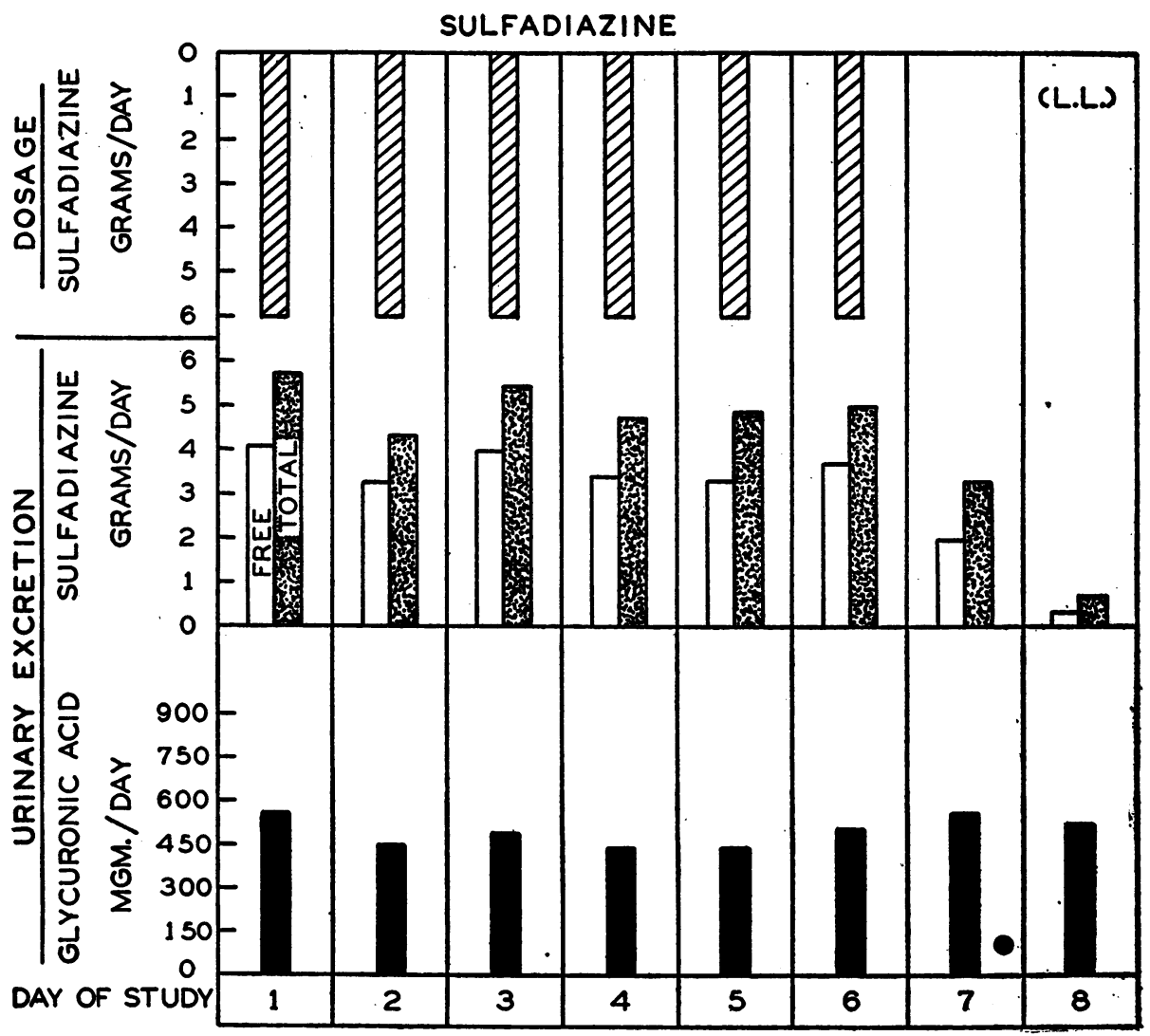

Fig. 3. Sulfadiazine

Patient L. L., an adult male, received 6 grams of sulfadiazine daily for 6 days in the treatment of pneumococcal pneumonia. The studies were begun during the 1 st day of therapy. 


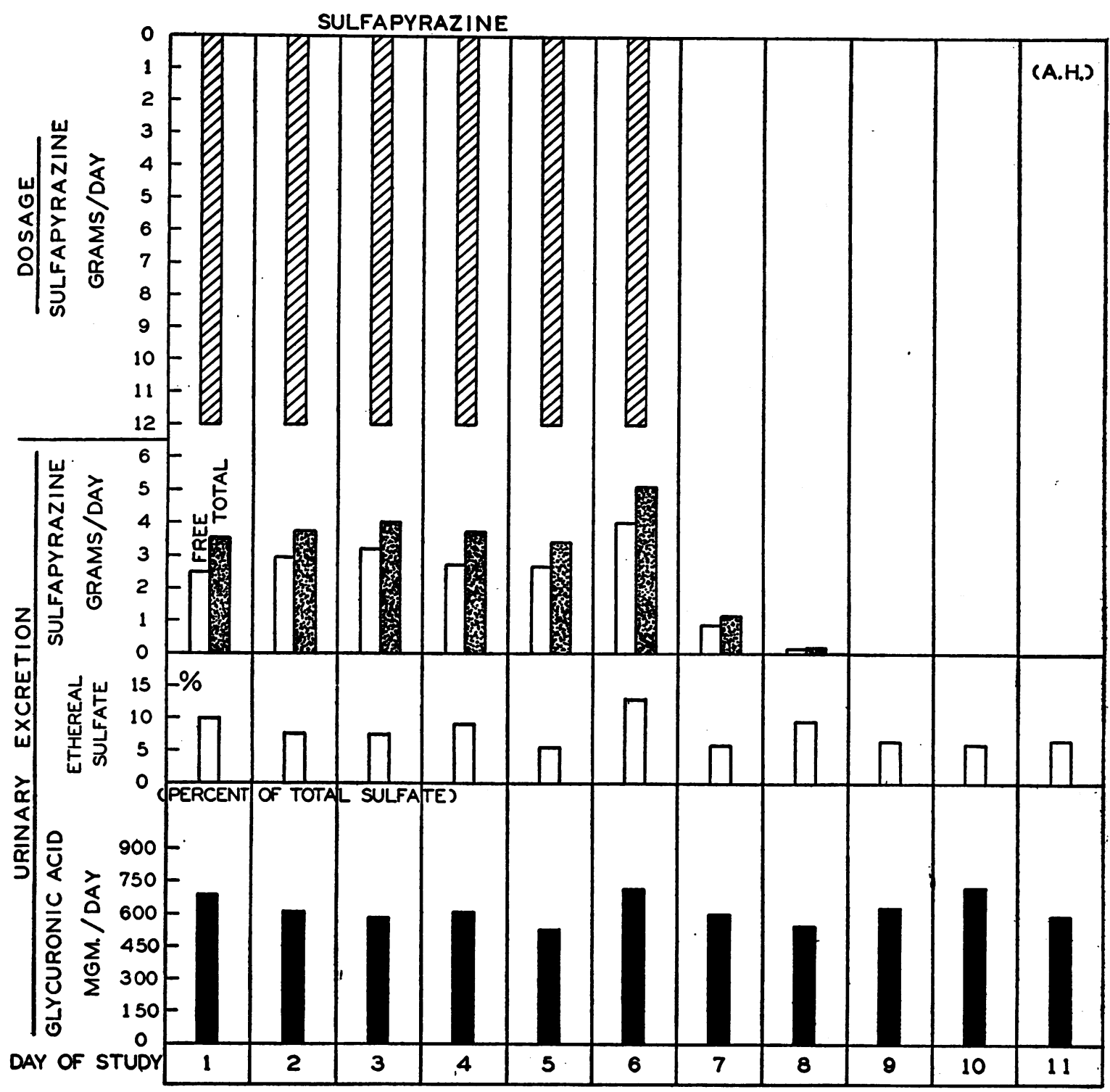

Fig. 4. Sulfapyrazine

Patient A. H., an adult female, received 6 grams of sulfapyrazine for 1 day, followed by 12 grams of this drug daily for 6 days in the treatment of pneumococcal pneumonia. The dosage of sulfapyrazine was increased to 12 grams on the $2 \mathrm{~d}$ day of therapy because the blood level of "free" sulfapyrazine was only $2.8 \mathrm{mgm}$. per 100 ml. after 1 day of treatment with 6 grams of the drug. This study was begun on the $2 d$ day of treatment.

(Figure 1) with sulfanilamide. Again, although no increase above normal in the ethereal sulfate excretion was found in our patient treated with sulfanilamide (Figure 1), a considerable increase in the ethereal sulfate excretion in rabbits after the ingestion of this drug has been reported (23).

Although it has been previously demonstrated that all of the sulfonamides studied in this inves- tigation become $\mathrm{N}^{4}$ conjugated to varying extents in man, and that this $\mathrm{N}^{4}$ conjugation is probably in nature always acetylation $(1,3,5$ to 7$)$, it has not been shown previously that any of these compounds except sulfapyridine (15) undergo chemical changes in man which lead to conjugations other than this $\mathrm{N}^{4}$ acetylation.

The findings of the present study confirm and 
TABLE II

Calculated percentages of urinary sulfonamides excreted as glycuronides (mono) as compared with percentages excreted as $N^{4}$ acetyl derivatives in the patients treated with sulfathiazole, sulfapyridine, sulfamerazine, and sulfamethazine

\begin{tabular}{|c|c|c|c|c|c|c|c|c|}
\hline \multirow{2}{*}{\multicolumn{2}{|c|}{$\begin{array}{l}\text { Patient and } \\
\text { figure number }\end{array}$}} & \multirow{4}{*}{$\begin{array}{l}\text { Drug administered } \\
\text { Sulfathiazole }\end{array}$} & \multirow{4}{*}{$\begin{array}{c}\begin{array}{c}\text { Average } \\
\text { dosage of } \\
\text { sulfonamide }\end{array} \\
\begin{array}{c}\text { grams per day } \\
6\end{array}\end{array}$} & \multicolumn{2}{|c|}{$\begin{array}{l}\text { Sulfonamide compound } \\
\text { excreted }\end{array}$} & \multirow{4}{*}{$\begin{array}{c}\begin{array}{c}\text { Increase in } \\
\text { urinary } \\
\text { glycuronic } \\
\text { acid over } \\
\text { control }\end{array} \\
\begin{array}{c}\text { mgm. per day } \\
160\end{array}\end{array}$} & \multirow{2}{*}{$\begin{array}{c}\text { Total } \\
\text { sulfonamide } \\
\text { excreted as } \\
N^{4} \text { acetyll } \\
\text { derivative }\end{array}$} & \multirow{2}{*}{$\begin{array}{c}\text { Total } \\
\text { sulfonamide } \\
\text { excreted as } \\
\text { monoglycu- } \\
\text { ronide }\end{array}$} \\
\hline & & & & Free & Total & & & \\
\hline & & & & \multicolumn{2}{|c|}{ grams per day } & & \multicolumn{2}{|c|}{ per cent } \\
\hline O. P. & Fig. 5 & & & 4.47 & 5.28 & & 15 & 4 \\
\hline B. D. & Fig. 6 & Sulfamerazine & 6 & 3.81 & 5.52 & 450 & 31 & 12 \\
\hline $\begin{array}{l}\text { M. R. } \\
\text { M. R. }\end{array}$ & $\begin{array}{l}\text { Fig. } 7 \\
\text { Fig. } 7\end{array}$ & $\begin{array}{l}\text { Sulfamerazine } \\
\text { Sulfamerazine }\end{array}$ & $\begin{array}{l}6 \\
3\end{array}$ & $\begin{array}{l}3.20 \\
1.68\end{array}$ & $\begin{array}{l}4.88 \\
2.67\end{array}$ & $\begin{array}{l}810 \\
445\end{array}$ & $\begin{array}{l}34 \\
37\end{array}$ & $\begin{array}{l}24 \\
24\end{array}$ \\
\hline R. N. & Fig. 8 & Sulfapyridine & 5.3 & 2.30 & 3.79 & 1115 & 39 & 41 \\
\hline M. C. & Fig. 9 & Sulfamethazine & 6 & 1.34 & 6.00 & 605 & 78 & 16 \\
\hline B.K. & Fig. 10 & Sulfamethazine & 4 & & 2.93 & 1300 & & 68 \\
\hline
\end{tabular}

quantitate the previous observation (15) that in man, the urinary glycuronide excretion is increased during the excretion of sulfapyridine, and further demonstrate that in man the urinary glycuronide excretion is also greatly increased during therapy with sulfamerazine and sulfamethazine, significantly increased with sulfathiazole, and not observably increased with sulfanilamide, sulfadiazine, and sulfapyrazine.

The products of the conjugation of these sulfonamides with glycuronic acid have not as yet been isolated from the urine of man and identified. The in vivo glycuronic acid derivative of sulfapyridine, isolated from the urine of dogs after sulfapyridine administration, has been demonstrated to be a glycuronic acid conjugate of an hydroxy derivative of the pyridine component of this drug $(13,14)$. It is of interest that although sulfadiazine itself does not lead to increased glycuronic acid excretion in man (Table I), when one methyl group is substituted in the 4-position of the pyrimidine radical of sulfadiazine or two methyl groups are substituted in the $4-6$ positions, the resulting drugs, namely sulfamerazine and sulfamethazine, respectively, do lead to greatly increased glycuronic acid excretion. There is evidence (22) that the products of the methylation of certain heterocyclic hydrocarbons other than pyrimidines undergo much greater or quite different chemical changes in vivo than do the parent compounds.

In vivo studies (24) indicate strongly that $\mathrm{N}^{4}$ acetylation of sulfanilamide occurs in the liver and not in any other tissue. Much evidence has been presented that with certain compounds other than sulfonamides, glycuronidation similarly takes place in the liver, and probably only in the liver (22). Further strong indication that glycuronidation of sulfonamide compounds occurs in the liver is the observation (16) that in rats with liver damage by phosphorous poisoning, the glycuronic acid excretion fails to increase after the ingestion of sulfapyridine.

With none of the drugs studied in this investigation was there any evidence of the formation in vivo in man of sulfated sulfonamide compounds. That glycuronidation takes precedence in man over sulfate formation with certain hydroxy compounds not of the sulfonamide group has already been demonstrated (25).

It is of interest that sulfapyridine, sulfamerazine; and sulfamethazine which become acetylated in man to an irregular and relatively large extent also become glycuronidated to a considerable extent (Table II), whereas sulfanilamide, sulfadiazine, and sulfathiazole which acetylate to a lesser extent show no or a very slight (sulfathiazole) tendency to glycuronidate. No general correlation between acetylation and glycuronidation is warranted since sulfapyrazine which acetylates irregularly in different patients and sometimes to a large extent (9) showed no tendency to glycuronidation in the patient of our study (A. H. Figure 4). It is of further interest that, 
whereas sulfadiazine becomes acetylated to a relatively small extent and does not become glycuronidated (Table I), its mono and di-methyl derivatives, sulfamerazine and sulfamethazine, respectively, become acetylated to a much larger and more variable extent and also become glycuronidated, the degree of these chemical changes appearing to be greater with the dimethyl derivative (Tables I and II).

Since a very large portion of the therapeutic dose of a sulfonamide drug may become chemically changed in the human body, and since the processes of "detoxication" vary greatly in different species, it is evident that studies of the in vitro bacteriostatic activity of any such drug and of its therapeutic and toxic properties in animals serve only to indicate the advisability of clinical trial. Thus, although sulfamethazine has approximately the same bacteriostatic activity in vitro (26) as do sulfadiazine and sulfathiazole and has been judged highly active against organisms in vivo in mice (10), it has not proved to be as reliable a therapeutic agent in man as are sulfadiazine and sulfathiazole $(11,27)$ in the same

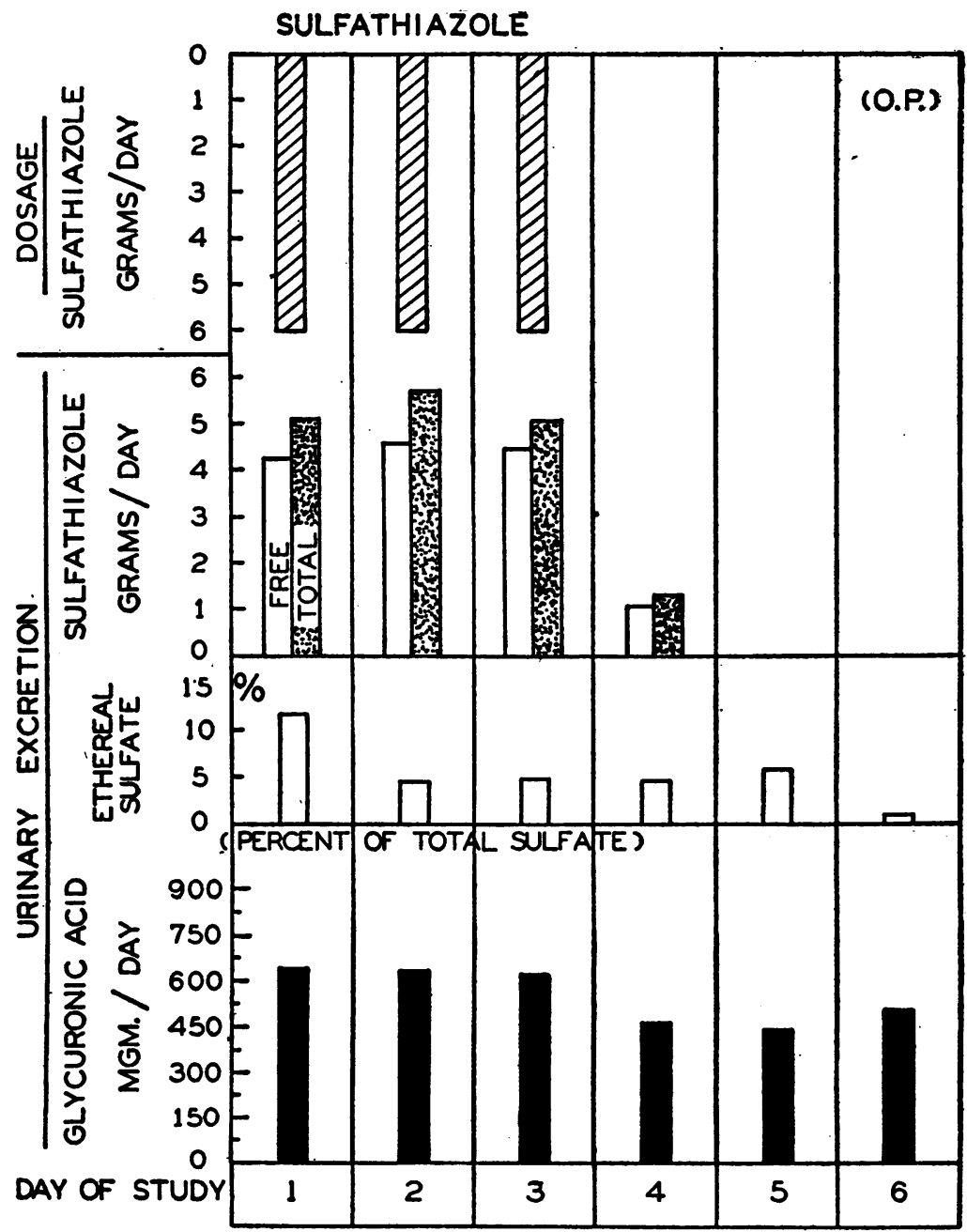

Fig. 5. Sulfathiazole

Patient O. P., an adult male, received 6 grams of sulfathiazole daily for 4 days in the treatment of a beta hemolytic streptococcus infection of the throat. The excretion studies were begun on the $2 \mathrm{~d}$ day of treatment. 
dosage. On'the basis of earlier studies (11), it was suggested that this lesser therapeutic value of sulfamethiazine was attributable to the fact that this drug became $\mathrm{N}^{4}$ acetylated to a large extent in a considerable number of patients, thereby losing a large part of its bacteriostatic activity. It may also be that of the portion of free compound remaining in the body a considerable amount may be glycuronidated. Although the data of this study do not afford direct infor- mation as to the exact nature of the glycuronidated compound, it is of interest that in M. C. (Table I), in whom sulfamethazine was very highly $\mathrm{N}^{4}$ acetylated, the calculated amount excreted as a glycuronide (Table II) was much less than in B. K. (Table I) who acetylated the drug to a much lesser degree. These findings possibly indicate that glycuronidation and $\mathrm{N}^{4}$ acetylation do not occur in the same molecule.

It has been previously demonstrated (22) that

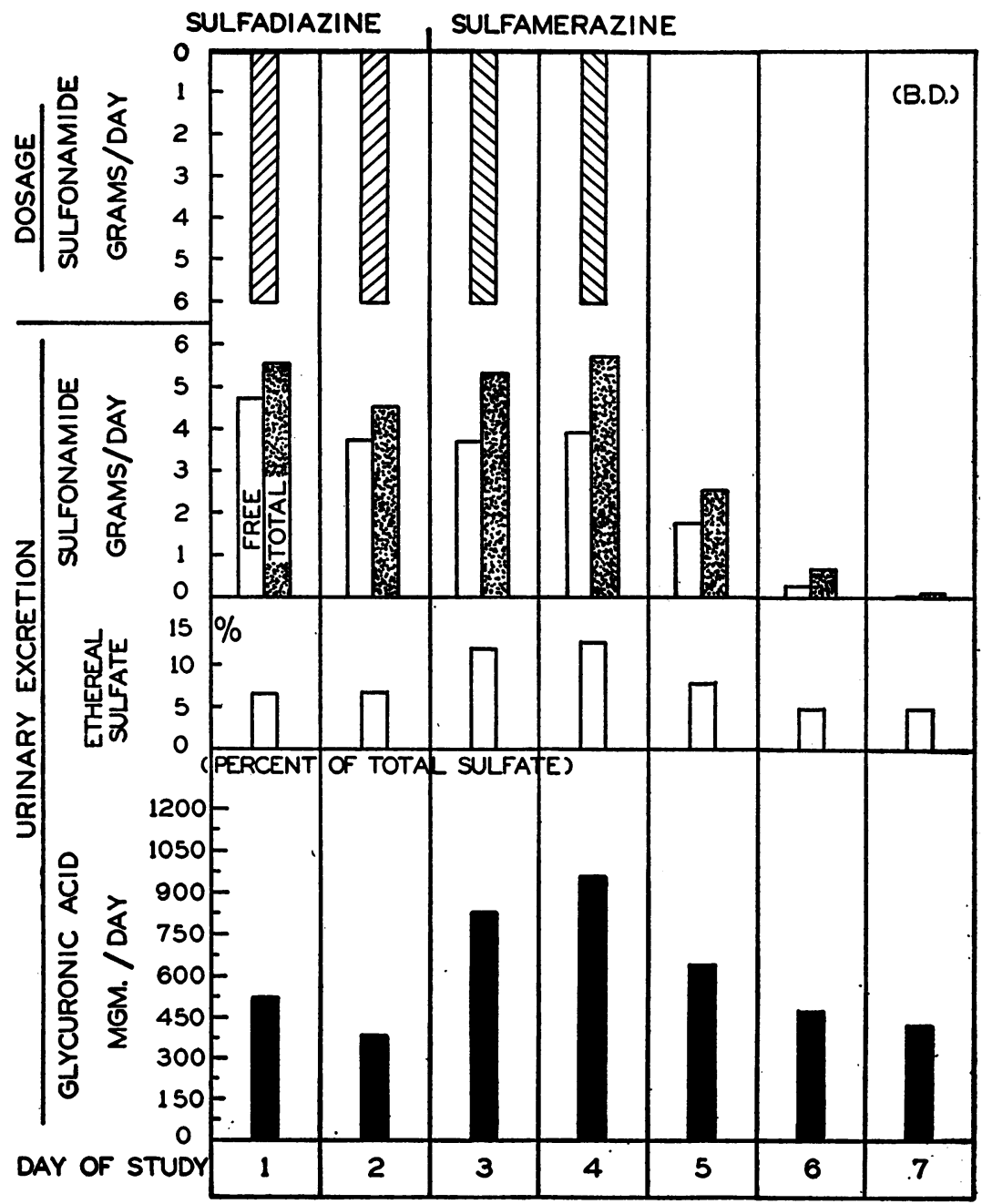

Fig. 6. Sulfadiazine, Sulfamerazine

Patient B. D., an adult female, received 6 grams of sulfadiazine daily for 3 days and 6 grams of sulfamerazine daily for the following 2 days in the treatment of pneumococcal pneumonia. Sulfadiazine was replaced by sulfamerazine on the 4th day of treatment in order to compare the findings of this study in the same subject with the two different drugs. The study was begun on the $2 \mathrm{~d}$ day of sulfadiazine therapy. 


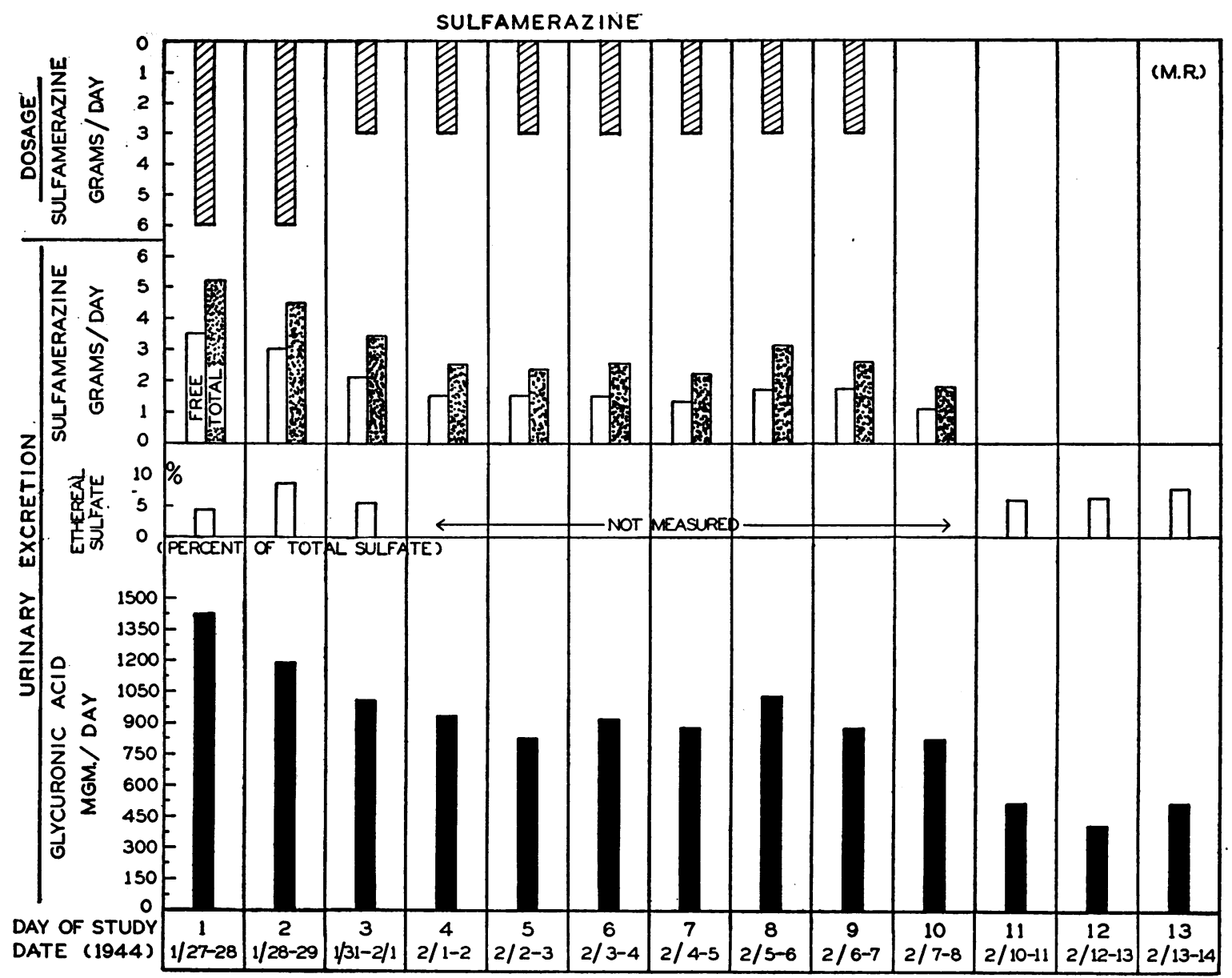

Fig. 7. Sulfamerazine

Patient M. R., an adult female, received 6 grams of sulfamerazine daily for 3 days and 3 grams of this drug daily for the following 9 days in the treatment of pneumococcal pneumonia and otitis media. The study was begun on the $2 \mathrm{~d}$ day of therapy.*

* Urine collections from this patient were known to be incomplete on the 1st and $2 \mathrm{~d}$ days of therapy with 3 grams of sulfamerazine, and on certain days during the control period. These days are indicated on the figure by the lack of complete continuity of the dates of study.

some foreign compounds, other than sulfonamides, which are not necessarily intrinsically toxic, owe their toxicity in part or in whole to those very in vivo reactions which lead to the formation of so-called "detoxication" products. That the in vivo $\mathrm{N}^{4}$ acetyl derivatives of several of the sulfonamide drugs in common usage may give rise to renal complications because they precipitate in the kidneys and urinary tract is well appreciated $(6,7)$. Whether the sulfonamide drugs administered or one of their in vivo derivatives gives rise to the febrile and skin reactions and the hematopoietic disturbances not infrequently observed is not known. That minute amounts of foreign compounds are sufficient to cause toxic reactions in man is well established. It has been suggested (28) that the cyanosis occurring during sulfanilamide therapy is due to the in vivo formation of an oxidizing agent by sulfanilamide.

It is to be pointed out that any renal clearance studies of sulfonamide compounds which are to have exact significance must be based on separate 

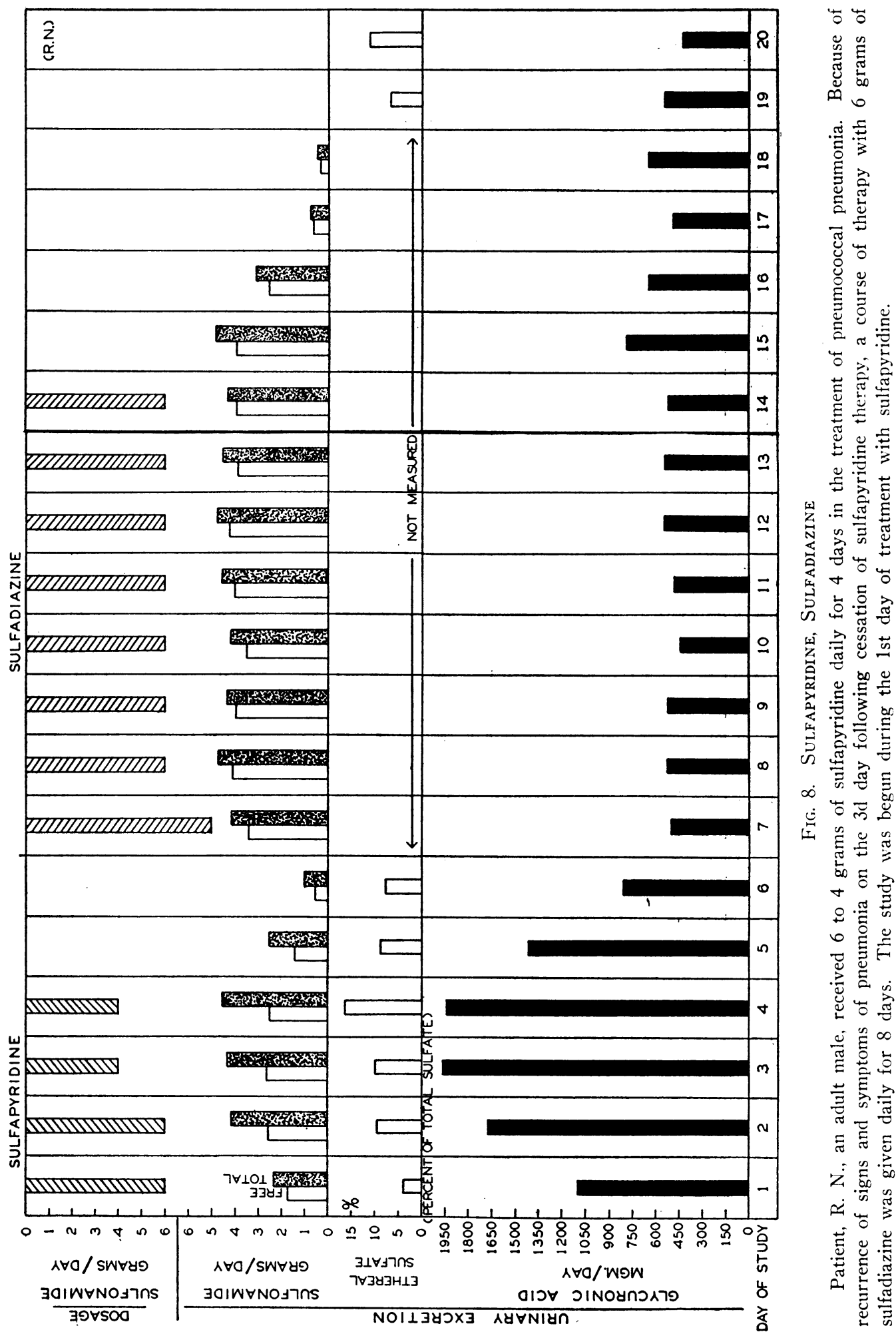


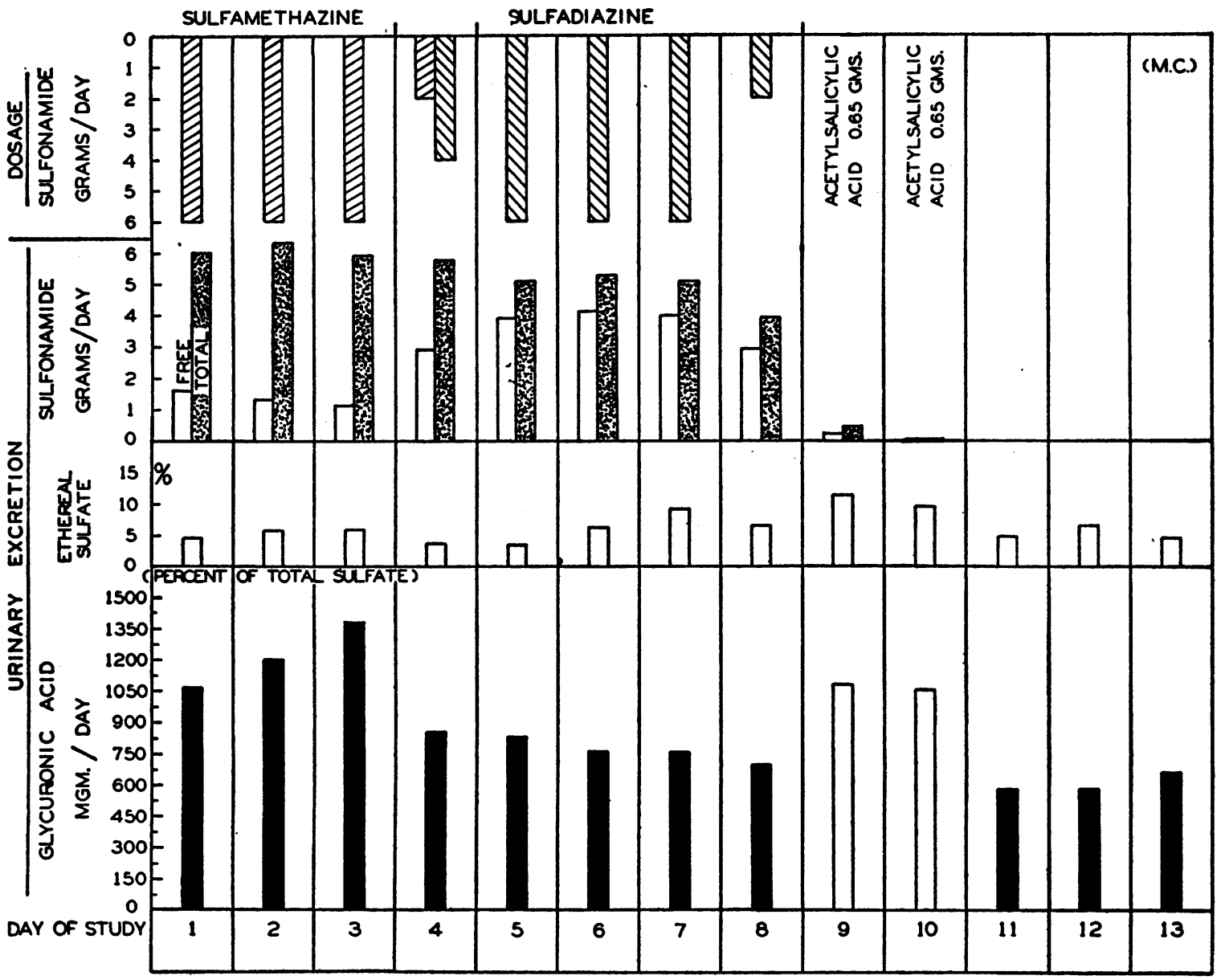

Fig. 9. Sulfamethazine, Sulfadiazine

Patient M. C., an adult female, received 6 grams of sulfamethazine daily for 4 days in the treatment of pneumococcal pneumonia. The study was begun during the 1st day of treatment. Sulfadiazine was given in place of sulfamethazine on the 5th day of treatment because the clinical response with the latter drug had not been satisfactory. The change in therapy afforded an opportunity for this comparative study of the fate of the two drugs. On the 9th and 10th days of study, 0.65 gram of acetylsalicylic acid was administered to the patient for the relief of pain from myositis. (N.B.-The glycuronide output was increased considerably during the acetylsalicylic acid medication.) This study was begun during the 1st day of sulfamethazine therapy.

studies of the several different compounds which may be present in the blood and urine of the particular species studied.

\section{SUMMARY AND CONCLUSIONS}

1. To gain information concerning the chemical changes which sulfonamide drugs undergo in man, studies of the urinary excretion of free and total sulfonamide compounds, of glycuronide, and of ethereal sulfates have been made in patients during and following therapy with sulfanilamide, sulfapyridine, sulfathiazole, sulfadiazine, sulfapyrazine, sulfamerazine, and sulfamethazine.

2. The results confirm previous reports showing the variability in the extent to which these drugs become $\mathrm{N}^{4}$ acetylated in man, sulfadiazine and sulfathiazole being the least acetylated and sulfamethazine the most in the subjects studied.

3. The ethereal sulfate excretion was not consistently increased above normal during therapy with any of these drugs. The data are interpreted to show that no appreciable amount of any 


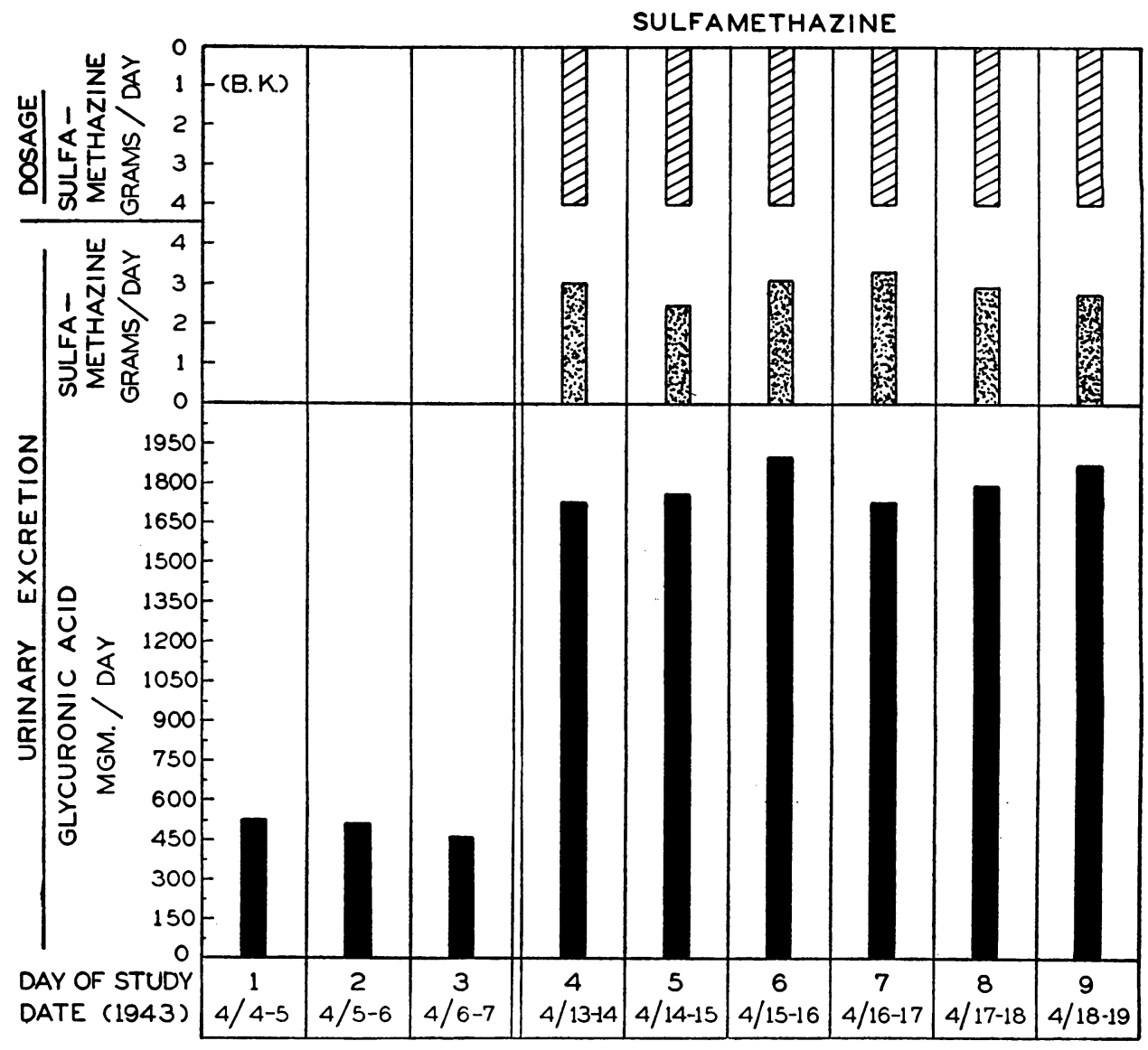

Fig. 10 . Sulfamethazine

Patient B. K., an adult male, received 4 grams of sulfamethazine daily for 12 days in the treatment of a urinary-tract infection with Staphylococcus aureus. Studies were made of the glycuronic acid excretion during 3 control days before sulfamethazine therapy was instituted and during the last 6 days of therapy when the patient was receiving 4 grams of the drug daily.*

* See footnote in legend of Fig. 2.

of these drugs or of any of their in vivo derivatives in man becomes sulfated.

4. The glycuronide excretion was not increased during therapy with sulfanilamide, sulfadiazine, or sulfapyrazine, was slightly increased with sulfathiazole, and was greatly increased during therapy with sulfapyridine, sulfamerazine, and sulfamethazine. These findings are interpreted as due to the formation of glycuronidated sulfonamide compounds in vivo.

5. Calculations based on the assumption that a monoglycuronide is formed in vivo show that from 4 per cent (with sulfathiazole) to 68 per cent (with sulfamethazine) of the total sulfonamide compounds excreted in the urine during therapy with sulfathiazole, sulfapyridine, sulfamerazine, and sulfamethazine were glycuronidated.

6. The findings have been discussed in relation to their bearing on the interpretation of in vitro studies of sulfonamide drugs, of in vivo studies in animals, and of existing data on the renal clearance of these drugs.

7. It has been pointed out that the toxicity and therapeutic value of a sulfonamide drug in man depend not only on these properties of the drug administered but on the properties of any of the 
several compounds which may be formed from the drug in vivo.

We wish to express our appreciation to Drs. Ephraim Shorr and Robert Furchgott for their many helpful suggestions during the progress of this work.

\section{BIBLIOGRAPHY}

1. Marshall, E. K., Jr., Cutting, W. C., and Emerson, $\mathrm{K}$., Jr., Acetylation of para-aminobenzenesulfonamide in the animal organism. Science, 1937, 85, 202.

2. Marshall, E. K., Jr., Bacterial chemotherapy. The pharmacology of sulfanilamide. Physiol. Rev., 1939, 19, 240.

3. Fuller, A. T., Is $p$-aminobenzenesulphonamide the active agent in prontosil therapy? Lancet, 1937, 1, 194.

4. Crossley, M. L., Northey, E. H., and Hultquist, M. E., Sulfanilamide derivatives. I. Aminoarylsulfonamidoarylsulfonic acids and aminoarylsulfonamidoarylcarboxylic acids. J. Am. Chem. Soc., 1938, 60, 2217.

5. Ratish, H. D., Bullowa, J. G. M., Ames, J. B., and Scudi, J. V., Urinary excretion products of sulfanilyl-2-aminopyridine. J. Biol. Chem., 1939, 128, 279.

6. Prien, E. L., and Frondel, C., Crystallography of the urinary sediments with clinical and pathological observations in sulfonamide drug therapy. J. Urol., 1941, 46, 748.

7. Gilligan, D. R., Garb, S., Wheeler, C., and Plummer, N., Adjuvant alkali therapy in the prevention of renal complications from sulfadiazine. J. A. M. A., 1943, 122, 1160.

8. Goodwin, R. A., Jr., Peterson, O. L., and Finland, M., Absorption and excretion of sulfamethyldiazine (2-sulfanilamido-4-methyl-pyrimidine) in human subjects. Proc. Soc. Exper. Biol. and Med., 1942, $51,262$.

9. Hamburger, M., Jr., Ruegsegger, J. M., Brookens, N. L., and Eakin, E. A., The absorption, excretion and distribution of 2-sulfanilamidopyrazine (sulfapyrazine) in man. Am. J. M. Sc., 1942, 204, 186.

10. Rose, F. L., Martin, A. R., and Bevan, H. G. L., Sulphamethazine (2-4'-aminobenzenesulphonylamino-4: 6-dimethylpyrimidine), a new heterocyclic derivative of sulphanilamide. J. Pharmacol. and Exper. Therap., 1943, 77, 127.

11. McDermott; W., Gilligan, D. R., Wheeler, C., and Plummer, N., Clinical studies of sulfamethazine. New York State J. Med., 1944, 44, 394.
12. Scudi, J. V., On the urinary excretion of "free" sulfapyridine. Science, 1940, 91, 486.

13. Scudi, J. V., Excretion of metabolic products of sulfapyridine in the dog. Proc. Soc. Exper. Biol. and Med., 1944, 55, 197.

14. Weber, C. J., Lalich, J. J., and Major, R. H., Metabolism of sulfapyridine in the dog. Proc. Soc. Exper. Biol. and Med., 1943, 53, 190.

15. Scudi, J. V., Ratish, H. D., and Bullowa, J. G. M., Increased glycuronate excretion following administration of sulfapyridine. Science, 1939, 89, 516.

16. Scudi, J. V., and Robinson, H. J., Urinary excretion of sulfapyridine in the rat. A relationship of the liver to urolithiasis. Am. J. M. Sc., 1941, 201, 711.

17. Bratton, A. C., and Marshall, E. K., Jr., A new coupling component for sulfanilamide determination. J. Biol. Chem., 1939, 128, 537.

18. Maughan, G. B., Evelyn, K. A., and Browne, J. S. L., A method for the quantitative estimation of glucuronic acid and conjugated glucuronides. J. Biol. Chem., 1938, 126, 567.

19. Kapp, E. M., Microestimation of uronic acids. J. Biol. Chem., 1940, 134, 143.

20. Fiske, C. H., see Peters, J. P., and Van Slyke, D. D., in Quantitative Clinical Chemistry, vol. II, Methods, The Williams and Wilkins Co., Baltimore, 1932, p. 894.

21. Folin, O., Laws governing the chemical composition of urine. Am. J. Physiol., 1905, 13, 66.

22. Young, L., The detoxication of carbocyclic compounds. Physiol. Rev., 1939, 19, 323.

23. Shelswell, J., and Williams, R. T., Studies in detoxication. 6. Ethereal sulphate formation in the rabbit after administration of sulphanilamide. Biochem. J., 1940, 34, 528.

24. Klein, J. R., and Harris, J. S., The acetylation of sulfanilamide in vitro. J. Biol. Chem., 1938, 124, 613.

25. Tollens, C., Über Glukuronsäure und Ätherschwefelsäuren im menschlichen Urine. Ztschr. f. physiol. Chem., 1910, 67, 138.

26. Bell, P. H., and Roblin, R. O., Jr., Studies in chemotherapy. VII. A theory of the relation of structure to activity of sulfanilamide type compounds. J. Am. Chem. Soc., 1942, 64, 2905.

27. Johnson, A. G., Sulphamethazine in gonorrhoea in the male. A report on fifty cases of gonococcal urethritis. Brit. J. Ven. Dis., 1944, $20,31$.

28. Harris, J. S., The in vitro formation of an oxidizing agent by surviving tissues and sulfanilamide. $\mathrm{J}$. Clin. Invest., 1939, 18, 521. 